\title{
Panevėžio kultūros išteklių vaidmuo formuojant miesto ivvaizdị
}

\section{Ieva Ucinavičiūtė,}

\section{Regina Prapiestienè}

Vilniaus universitetas, M. K. Čiurlionio g. 21/2, 03101 Vilnius, Lietuva

El.paštas: ieva.ucinaviciute@gf.stud.vu.lt; regina.prapiestiene@gf.vu.lt
Ucinavičiūtė I., Prapiestienė R. Panevěžio kultūros išteklių vaidmuo formuojant miesto ịvaizdį. Geologija. Geografija. 2017. T. 3(3). ISSN 23517549 .

Miesto įvaizdis šiuolaikiniame pasaulyje yra svarbus daugeliu aspektų. Jis reikšmingas norint pritraukti naujų investicijų, gyventojų ar turistų, tai lemia sẻkmingą miesto plètrą. Mokslinèje literatūroje teigiama, kad ịtakos ivvaizdžiui gali turèti daugelis veiksnių. Tai ir fiziniai miesto aplinkos elementai, žiniasklaidos pranešimai viešojoje erdvejje, taip pat kitų asmenų nuomonè ar miesto įžymybès. Panevėžys praeityje garsèjo įvairiais kultūros ištekliais: teatrų veikla, švietimo įstaigomis, meno ir muzikos kolektyvais, jame yra nemažai paveldo objektų. Tinkamai reprezentuojami kultūros ištekliai taip pat gali tapti viena priežasčiu, garsinančiu miestą. Šiame darbe bandyta išsiaiškinti, kokie Panevéžio miesto ištekliai yra reikšmingi formuojant jo ivvaizdi, koks miestas atrodo jo gyventojams ir ar kultūros ištekliai turi tam itakos.

Raktažodžiai: kultūra, kultūros ištekliai, miesto ịvaizdis, ịvaizdžio formavimas, îvaizdžio formavimo veiksniai

\section{IVADAS}

Šiuolaikiniame globaliame pasaulyje miestams sèkmingai vystytis ir konkuruoti rinkoje tampa vis aktualiau. Susikurtas ir pristatomas miesto ivaizdis yra svarbus kriterijus vartotojams priimant sprendimus kur apsigyventi, išvykti atostogų, ieškotis darbo ar pramogu galimybių. Tai, kokią informaciją apie miestą yra girdejjusi ir kaip ji Ł̇sivaizduoja tikslinè auditorija, pavyzdžiui, paslaugų vartotojai, potencialūs partneriai, investuotojai, verslo klientai, turistai ir t. t., yra reikšminga miesto ekonominei, socialinei, demografinei sèkmei. Konkurencija tarp miestų didelè, todèl laimi tie, kurie žino, kaip išnaudoti savo geriausius bruožus, juos reprezentuoti, išsiskirti iš kitų panašaus dydžio ar statuso miestų.
Kartais gali būti sunku teisingai suprasti, kas yra tas miesto ịvaizdis, kas jị kuria ir ị ką reikètų atkreipti demesi norint patraukliai ji formuoti. İvaizdžio konsultantè viename interviu teigia, kad ịvaizdi galima apibūdinti kaip visuotinai vyraujanti stereotipą apie tam tikrą objektą, kuris yra neatsiejamas bei privalomas norint būti populiariam, svarbiam, vertinamam. İvaizdis nebūtinai kuriamas specialiai, sąmoningai, tačiau bet koks objektas ar žmogus turi tam tikrą „veidą“, kuris yra žinomas ar atpažistamas (AlbrechtaitèLingienè, 2012).

Turbūt įtakingiausi yra Kevino Lyncho atlikti moksliniai tyrimai ịvaizdžio formavimosi srityje. Šis urbanistikos ir planavimo specialistas teigia, kad žmonès, suvokdami miestų aplinką, susistemina juos $\mathfrak{i}$ pasikartojančius elementus, tokius 
kaip keliai (angl. paths), kraštai (angl. edges), rajonai (angl. districts), mazgai (angl. nodes) ir orientyrai (angl. landmarks) (Lynch, 1960). Šie elementai bei juos supanti aplinka geriausiai issimena žmonėms, nes esant šalia jų yra priimami reikšmingi sprendimai, kas priverčia žmones labiau sutelkti dèmesị $\mathfrak{i}$ aplinkos detales ir aiškiau ją suvokti.

Amerikiečių marketingo specialisto Philipo Kotlerio nuomone, miestai gali naudotis savo susikurtu prekiniu ženklu, norèdami skleisti tam tikrą žinią tikslinėms auditorijoms. Pirmas žingsnis kuriant miesto prekinị ženklą yra miesto įvaizdžio nustatymas. I̦vaizdis yra įsitikinimų, idejų ir ìspūdžių rinkinys, kurị tam tikras asmuo turi susidaręs apie miestą. Todèl ịvaizdis, pasak autoriaus, yra psichinis miesto vaizdas žmogaus mintyse, kuri kiekvienas asmuo susikuria individualiai. Suprasti tokius psichinius vaizdus svarbu, nes žmonių požiūris ir veiksmai tam tikrame mieste yra nulemti būtent to miesto įvaizdžio (Gilboa ir kt., 2014).

Savo išskirtinị ir gerai visiems žinomą ịvaizdị turi suformavę tiek daugelis pasaulio, tiek Lietuvos miestų. Varžomasi, kuriuose miestuose geriausia gyventi, atostogauti, igyti kokybišką aukštąji išsilavinimą ir pan. Ne visų miestų ịvaizdis yra patrauklus visuomenei, kartais kai kurie miestai laikomi nesaugūs, pavojingi, $\mathfrak{j}$ kuriuos geriau visai nevykti. Taip yra todèl, kad ịvaizdis gali susiformuoti ir to specialiai nesiekiant, priklausomai nuo aplinkos veiksnių (klimatas, ekonominè situacija, kariniai konfliktai ir t. t.). Tačiau tai vis tiek turi įtakos miestų populiarumui, jų egzistencijai ir plètrai.

$\mathrm{Su}$ Lietuvos miestais situacija panaši: vieni vertinami palankiau nei kiti, kai kurie sulaukia didesnių turistų srautų, o kartu ir daugiau pajamų, verslo investicijų, migracijos srautai taip pat tendencingi - iš vienų miestų daugiau išvažiuojama, ị kitus atvažiuojama gyventi, dirbti, pramogauti. Šiame moksliniame darbe analizuojamas Panevėžio miesto ịvaizdis, siekiama išsiaiškinti, kokie veiksniai jam turi daugiausia ịtakos. Nors atsižvelgiama ị daugelị miesto aplinkos aspektų, ìvairius miesto erdvès objektus, gilinamasi, ar miesto kultūros, kultūros paveldo ištekliai reikšmingai prisideda prie jo formavimo.

Toks tyrimo objektas pasirinktas ne atsitiktinai. Kultūros paveldas šiuolaikiniame pasaulyje tampa vis labiau aktualus. Jis yra svarbus tiek miestų, tiek natūralių gamtinių šalies teritorijų traukos objektas. Taip garsinama vietove, pritraukiama ị ją investicijų, darbo jègos. Kultūrinis turizmas yra daugelio miestų ir jų gyventojų pagrindinis pragyvenimo šaltinis, išsigelbejimas, jei vietovèje neịmanoma pramonès ar žemès ūkio plètra. Dèl kultūrinių išteklių formuojama tiek miesto gyvenamoji erdvé, tiek žmonių savimoné, jų tapatumas. Šiais laikais vis labiau kinta supratimas ir kultūros paveldo panaudojimas miestuose, pavyzdžiui, pramoninèse teritorijose, kur buvo vykdoma gamyba, o dabar likę tik tušti, neestetiški pastatai, organizuojamos ekskursijos, driekiasi turistiniai maršrutai, juose ikuriamas tam tikros tematikos muziejus. Išlikęs kultūrinès praeities paveldas, apgalvotai naudojamas ir originaliai pristatomas, yra tinkamas laisvalaikiui praleisti, naujoms verslo idejomis formuoti (Robinson, 2009).

\section{PANEVĖŽIO MIESTO İVAIZDŽIO TYRIMO METODIKA}

Darbo tyrime analizuojamas kultūros išteklių indèlis $\mathfrak{i}$ Panevéžio miesto îvaizdžio formavimą. Pasirinktas lyginamosios analizès metodas. Nagrinejjami ịvairūs straipsniai, leidiniai, susiję su miesto istorija, taip pat informacijos ieškota kultūros įstaigų interneto portaluose. Analizei pasirinktas laikotarpis iki $1990 \mathrm{~m}$. ir po jų, nes tuo metu stipriai keitèsi tiek ekonominé, tiek politine situacija Lietuvos miestuose, buvo atkurta šalies nepriklausomybè, todèl pasikeitè ir miesto kultūrinis gyvenimas, radosi daug naujų i̇monių, ìstaigų, užsiimančių ịvairia kultūrine veikla. Tai galèjo turèti ịtakos keičiantis ir visuomenès nuomonei apie Panevèžio miestą.

Atlikus šią lyginamąją analizę buvo parengta 15 klausimų anketa, apklausti Panevėžio miesto ir rajono gyventojai tiek internetineje erdveje, tiek gyvai. Anketai platinti pasitelktas „sniego gniūžtès" principas, kada apklausos atlikèjas pasirenka kelis jam lengvai pasiekiamus tiriamuosius, išdalina anketas, o šie pasiūlo jas dar kitiems potencialiems tiriamiesiems.

Anketoje pateiktus klausimus galima suskirstyti $\mathfrak{i}$ keturias grupes. Pirmosios grupès klausimai skirti išsiaiškinti kontaktinę informaciją apie respondentą: ar jis gyvena Panevėžio miesto, ar 
rajono savivaldybeje; kiek laiko ten gyvena; kokia jo lytis, amžius ir profesinè veikla. Tai naudinga aiškinantis apklaustųjų atsakymų dèsningumus. Antrosios grupès klausimai buvo skirti nustatyti, koke yra reikšmingiausi ịvaizdi apie Panevėžio miestą formuojantys veiksniai. Likerto skalès principu (Likert..., 2006) buvo suformuluoti klausimai, prašyta ịvertinti tam tikrus miesto fizinius, ekonominius ar kultūrinius reiškinius, atsakymams pasirenkant variantus nuo „vertinu labai gerai“, „vertinu gerai“, „vertinu vidutiniškai“ iki „vertinu blogai“, „vertinu labai blogai“ ir „neturiu nuomonès“. Šie klausimai padèjo išsiaiškinti, kas mieste vertinama geriausiai, kas prasčiausiai, kas labiausiai lemia miesto įvaizdị. Trečioji grupè klausimų padèjo atskleisti, koks Panevėžio miesto įvaizdis respondentams jau yra susiformavęs, buvo prašoma ịvertinti (Likerto skalès principu), koks yra miesto ịvaizdis Lietuvoje ir apskritai koks, respondentų nuomone, yra Panevèžio ivaizdis.

Vieni iš svarbiausių anketoje buvo ketvirtosios grupès klausimai apie įvaizdžiui miesto kultūros išteklių daromą ịtaką. Pavyzdžiui, respondentų buvo prašoma pažymèti labiausiai, jų nuomone, Panevèži garsinančius kultūros išteklius. Taip siekta išsiaiškinti labiausiai garsinančius ir reprezentuojančius Panevėži kultūros išteklius, kurie, didelè tikimybè, turi ịtakos miesto ịvaizdžio formavimui. Taip pat anketoje respondentai žymejjo kultūrinius renginius, izžymius asmenis bei kultūros objektus, kurie, jų ịsitikinimu, „labai garsina“ miestą, „mažai garsina“ arba yra „visai nesusiję su miestu“. Šis klausimas buvo reikalingas aiškinantis asociacijas su Panevėžio miestu, daug ar mažai renginių / objektų / asmenybių reprezentuoja miestą.

Pasitelkus statistinị ir loginị tyrimo metodus anketinès apklausos rezultatai buvo apdoroti ir išanalizuoti. Statistinio ir kartografinio tyrimo metodų pagalba rezultatai pateikti ịvairių formų vaizdine medžiaga: lentelèmis, paveikslèliais, kartoschemomis.

\section{TYRIMO REZULTATAI}

\section{Miesto kultūrinė erdvė iki 1990-uju ir vẻliau}

Pasak įvairių istorinių šaltinių, iki 1990 m. kultūrinè sfera mieste klestejo. Ona Maksimaitienè knygoje apie Panevėžio miesto istoriją užsimena apie aktyvią švietimo ịstaigų kultūrinę veiklą, išugdžiusią daug to meto visuomenès veikèjų, bendruomeninių kolektyvų, garsinusių miestą kultūros srityje, pavyzdžiui, švietimo draugijos „Saule“", „Rytas“, „Žiburys“, Gimtajam kraštui ginti draugija, kuri vẻliau ịsteige Kraštotyros muziejų, ir kt. (Maksimaitiené, 2003). Panevéžio miesto istorija neatsiejama ir nuo jo teatrinès kultūros formavimosi. Miesto unikalios kultūros įstaigos - lèlių vežimo teatras, muzikinis teatras - buvo svarbūs traukos objektai žmonėms iš visos Aukštaitijos, o teatro vadovas J. Miltinis spektakliais garsino Panevėžį už Lietuvos ribų. Panevèžyje nuo seno buvo žinoma kino mégejjų draugija, kurios sukurti mejgejjiški filmai Sovietų Sąjungoje buvo vieni geriausių (Dranseikaite, 2011).

Po 1990-ųjų mieste ìsikūrè kelios naujos kultūros įstaigos, pavyzdžiui, teatras „Menas“, meno galerijos, muziejai, kurios vykdo kultūrines, edukacines ar pramogines veiklas. Jos organizuoja daugelį vietinių ir tarptautinių renginių, kurie yra konkurencingi kitiems Lietuvos renginiams, puikiai reprezentuoja Panevėžio miestą. Kultūros plètros studijoje (Panevéžio miesto kultūros..., 2012) ìvardijama daugelis tarptautinio masto kultūros renginių: keramikos ir akmens skulptūrų simpoziumai, kamerinių spektaklių festivaliai, lèlių teatrų festivalis „Lagaminas“ ir kt. Galima teigti, kad po 1990 m. kultūrinè sfera pakito, tapo ivvairesné, labiau globali, plačiau skleidžianti informaciją apie Panevežzi.

\section{Anketinès apklausos bendroji informacija}

Iš viso anketinès apklausos atsakymus pateikè 188 respondentai. Didžioji dalis respondentų - moterys, jų dalyvavo 141 (75\%), vyrų - 47 (25\%). Pagal amžiaus grupes tyrime daugiausia dalyvavo 18-27 metų jaunimas (71 respondentai, arba $37,8 \%)$ ir vyresni darbingo amžiaus žmonès (101 respondentas, arba 53,7 \%). Nedidelę dali apklaustųjų sudarè jaunimas iki 18 metų (6 apklaustieji, 3,2 \%) bei pensinio amžiaus žmonès - nuo 64 metų ir daugiau (10 apklaustųjų, 5,3 \%).

Išanalizavus tyrime dalyvavusius respondentus pagal gyvenamąją vietą paaiškèjo, kad didžioji dalis jų gyvena Panevèžyje (137 apklausos dalyviai, 72,9\%), ketvirtadalis apklaustujų buvo iš Panevėžio rajono savivaldybès (48, arba 25,5\%), 
trys apklaustieji savo gyvenamajai vietai apibūdinti pasirinko atsakymo variantą „kita“.

\section{MIESTO İVAIZDİ FORMUOJANTYS VEIKSNIAI}

Analizuojant kultūros išteklių ịtaką miesto ịvaizdžiui pirmiausia buvo išsiaiškinta, kokie bendri veiksniai lèmé tam tikrą respondentų nuomonę apie Panevėži. Apklausoje buvo pateikta daug skirtingų miesto visumos elementų ir prašoma pažymėti, kaip respondentai juos vertina. Panaudotas Likerto skalès principas (Likert scaling, 2006), kai respondentai, vertindami ịvairius aspektus, turi galimybę pasirinkti iš variantų „labai gerai“, „gerai“, „vidutiniškai“, „blogai“, „labai blogai“, "nežinau“. Pagal tai galima spręsti, kas, apklaustųjų nuomone, labiausiai formuoja Panevèžio miesto ịvaizdị. Daugiausia teigiamų vertinimų surinko miesto geografinè padètis, žaliosios erdvès, parduotuvès ir prekybos centrai, galimybẻ sportuoti mieste, įžymūs Panevėžio žmonès. Šiuos kriterijus respondentai laiko labiausiai reprezentuojančiais miestą.

2014-2020 m. Panevéžio miesto plètros strateginiame plane miestas apibūdinamas kaip esantis patogioje geografineje padètyje, kur susikerta kelios svarbios automagistralès, viena jų - tarptautinè Via Baltica, jungianti Panevėži su Vilniumi ir Latvijos sostine Ryga, taip pat miestą kerta geležinkelio linija. Šie miesto privalumai teikia jam didesnę vertę ir gali prisidèti prie ịvaizdžio gerinimo (Panevéžio miesto plètros..., 2013). Plane taip pat teigiama, kad mieste gerai išplètotas prekybos įstaigų tinklas, $2011 \mathrm{~m}$. buvo 664 mažmeninès prekybos ìstaigos, kartu su maitinimo, maisto prekių, drabužių, avalynès ir kitų prekių parduotuvėmis (Panevėžio miesto pletros..., 2013). Panevėžio Turizmo ir informacijos centras nurodo Panevėžyje esančius prekybos ir pramogų centrus, kuriuose aktyviai lankosi ne tik miesto gyventojai, bet ir atvykstantys svečiai. Juose galima rasti įvairaus pobūdžio parduotuvių ir paslaugų.

Panevėžys jau seniai garsina savo vardą propaguodamas ịvairias sportines veiklas. Lietuvos sporto statistikos metraštis pateikia informaciją apie $2014 \mathrm{~m}$. Lietuvos savivaldybių sporto bazes. Pagal ji, Panevėžio miesto teritorijoje yra nemažai sportine veikla užsiimti tinkamų vietų: trys sporto kompleksai, viena sporto arena, penki stadio- nai, lengvosios atletikos maniežas, du baseinai, 32 ivvairaus dydžio sporto salès, dviračių trekas, aerodromas, irklavimo sporto bazè, 22 krepšinio aikštelès ir t. t. (Lietuvos sporto..., 2015).

Panevėžyje didelị rekreacinị potencialą turintys želdynų plotai išsidestę abipus Nevéžio upès krantų, ši teritorija miesto želdynų tvarkymo specialiajame plane vadinama Panevėžio žaliąja ašimi (Panevėžio miesto želdynų..., 2013). Kairiajame upès krante yra Skaistakalnio, Senvagès, Kultūros ir poilsio bei Nevėžio slènio pievų parkai. Dešiniajame krante tęsiasi Berčiūnų, Nevėžio upès pakrantès miško ir pievų parkai. Didžiausi želdynų plotai išsidèstę centrinejje miesto dalyje, jie labiausiai prižiūrimi. Patrauklumo žaliosioms erdvèms suteikia ịvairūs menininkų sukurti paminklai, skulptūros, mažosios architektūros elementai, tokių yra Senvageje bei centriniuose skveruose. Tai pastebèjo ir įvertino respondentai.

Apklausos dalyviai buvo prašomi įvertinti ir miesto kultūrini gyvenimą. Šio darbo tyrimui tai svarbu, kadangi aiškinamasi, ar didelę įtaką miesto įvaizdžiui turi kultūra ir kultūros ištekliai. Kaip buvo užsiminta straipsnio metodikoje, Panevėžyje nuo seno egzistavo ir iki šiol tebèra nemažai isstaigų, kurios vykdo kultūrines, edukacines ar pramogines veiklas miesto gyventojams. Tai itin svarbus kultūrinis išteklius, nes organizuojami ir vietiniai, ir tarptautiniai renginiai. Iš 188 apklausoje dalyvavusių žmonių 71 kultūrinị miesto gyvenimą ịvertino „gerai“, 87 - „vidutiniškai“. Vadinasi, didžiajai daliai respondentų jų nuomonè apie miesto ịvaizdị tampriai susijusi su miesto kultūriniu gyvenimu, tačiau šiuo aspektu žmonès nèra visiškai patenkinti dabartine situacija, galbūt patys nepakankamai domisi šia sritimi arba trūksta informacijos viešojoje erdvejje.

Likę elementai labiau prisideda prie neigiamo ìvaizdžio formavimo. Itin daug vertinimų „vidutiniškai“ sulaukè gyventojų mentalitetas, saugumas mieste, keliai, ekonominė padètis. Lietuvoje Panevėžys buvo pagarsejjęs nusikalstama veikla užsiimančių grupuočių gausa, ìvairiais kriminaliniais ìvykiais, kas tiek gyventojams, tiek asmenims iš Panevėžio rajono suformavo nesaugios vietos ịvaizdị, išlikusị iki šiol. Apklausa rodo, kad panevèžiečiai patys vertina miesto gyventojų kultūrą, charakteri gana neigiamai, mentalitetas nuo sovietinių laikų labai nepasikeite, nekuria malonaus miesto įspūdžio. 
Keliu būklè, apklausos duomenimis, yra prasta, todèl kelionès mieste yra nekomfortiškos, gadina ir miesto įvaizdį. Pasitvirtina minèto urbanisto Kevino Lyncho pateikta teorija, kad žmonès, suvokdami miestų aplinką, ypač atkreipia dèmesi i $\mathfrak{z}$ vieną iš šešių elementų - miesto kelius. Keliai - tai elementai, kuriais judama, kartu stebima aplinka, su ja susipažįstama, todèl jei keliai nekokybiški, trukdo žmogui tinkamai suvokti aplinką, ir pirmas ịspūdis ịvažiavus ị miestą nebus teigiamas (Lynch, 1960).

Neigiamą vertinimą dèl miesto ekonominès padèties galejo nulemti ir bendra Lietuvos ekonominè situacija, maži žmonių atlyginimai, sunkumai ieškantis darbo. Respondentų nuomonè sutampa su prekinio ženklo eksperto Simono Anholto paskelbtomis šešiomis ịvaizdžio formavimo dimensijomis. Viena jų - miesto potencialas, ekonominès ir švietimo galimybès mieste. Autoriaus teigimu, tai vienas iš svarbiausių aspektų kuriant patrauklų miesto ịvaizdị (Anholt, 2006). Todèl tai, kad respondentai šią sritị vertina prastai, reiškia, kad Panevèžio įvaizdžiui ekonomika ir švietimo perspektyvos daro neigiamą itaką.

Tyrimo metu išsiaiškinta, kas, respondentų manymu, atsakingas už suformuotą dabartinį miesto i̇vaizdị. Didžioji dalis apklaustųjų nusprendè, kad miesto valdžia yra labiausiai atsakinga už tinkamo įvaizdžio formavimą (45,6 \% apklaustųjų). Nemažai manančiųjų, kad reikšmingą ittaką turi ir patys miesto gyventojai, taip teigia $31,4 \%$ respondentų. Visuomeninems organizacijoms atsakomybę už miesto vardo ir įvaizdžio kūrimą priskyrẻ $14,5 \%$, o žiniasklaidai $-7,1 \%$ apklaustųjų. Tai rodo žmonių sąmoningumą - jie supranta, kad nuo kiekvieno gyventojo pastangu priklauso, kaip jie patys jausis mieste, ką gero padarys miestui, kad išspręstų jo problemas bei prisidètų prie teigiamo Panevéžio įvaizdžio formavimo.

\section{PANEVĖŽIO MIESTO İVAIZDIS}

Siekiant nustatyti, koks yra kultūros išteklių vaidmuo miesto ịvaizdžiui, pirmiausia buvo išsiaiškinta bendra gyventojų nuomonè apie miestą. Tyrime dalyvavę apklaustieji ịvertino Panevėžio miesto ìvaizdi Likerto skalès principu (Likert scaling, 2006) nuo „labai gerai“ iki „labai blogai“. Daugiau nei puse apklaustųjų (105, arba 56,4\%) mano, kad miesto įvaizdis vidutiniškas, 11,2 \% (22 respondentai) teigia, kad ivaizdis blogas, 3,2 \% (6 respondentai) - kad labai blogas. Teigiamą nuomonę išreiške žymiai mažiau respondentų $-27,7 \%$ (48 apklaustieji).

Toks vertinimas gana abstrakčiai apibūdina respondentų nuomonę apie miesto įvaizdį. Vertinant konkrečiau, tyrime dalyvavę asmenys iš pateiktų teiginių apie Panevèžio miestą rinkosi, su kuriais sutinka, su kuriais ne (žr. lentelę). Lentelès duomenys rodo, koks ir su kokiais miesto aplinkos aspektais susijęs Panevèžio miesto ivaizdis yra priimtiniausias respondentams. Paryškinti skaičiai reiškia, kad teigini ịvertino daugiau nei puse apklaustųjų. Spalvos intensyvumas simbolizuoja reikšmes nuo mažiausia atsakiusiųjų (šviesiausia spalva) iki daugiausia (ryškiausia spalva).

Respondentai dažniausiai sutiko su šiais teiginiais: Panevéžys - žalias miestas, turintis daug gamtos; Panevéžys - sporto miestas ir miestas su mažai darbo vietų. Šiuos teiginius pasirinko daugiau nei pusė apklausos anketą užpildžiusių asmenų. Du pirmi teiginiai rodo, kad gyventoju susidarytas ịvaizdis apie miestą gana teigiamas: graži gamta, kurioje galima poilsiauti, o sporto užsièmimai laisvalaikiu yra vieni iš didžiausių Panevėžio privalumų, gana svarbūs miesto traukos veiksniai. Nuomone, kad mieste mažai darbo vietų, greičiausiai susijusi su anksčiau minèta prasta ekonomine miesto padètimi, Panevėžio patrauklumą menkina. Vienas iš svarbiausių aspektų, galinčių pritraukti naujų gyventojų i miestą, tai darbo paieškos, o vyraujant nuomonei, kad mieste sunku rasti darbą, neigiamai paveikiami migracijos srautai i miestą.

Didelè dalis (83 atsakiusieji) sutinka su teiginiu, kad Panevèžys - Aukštaitijos kultūros centras. Miestas jiems asocijuojasi su kultūros renginių ir veiklos gausa, be to, jau nuo seno, net ir prieš Lietuvos nepriklausomybès atkūrimą, apylinkių gyventojus į miestą traukdavo jame esančios kultūros ístaigos - teatrai, kinas, bibliotekos ir kt. Tokia vyraujanti respondentų nuomonė yra labai didelis pliusas Panevėžiui, kuris ateityje turètų orientuotis $\mathfrak{i}$ kultūros išteklių gerinimą, tai būtų kaip priemonè patrauklesniam ịvaizdžiui formuoti. Be to, respondentu atsakymai parodé, kad kultūros ištekliai miesto ịvaizdžiui yra labai reikšmingi. 
Lentelè. Teiginiai ir jų vertinimo rezultatai

Table. Statements about Panevėžys city and evaluation results

\begin{tabular}{|c|c|c|c|c|c|}
\hline & $\begin{array}{c}\text { Visiškai } \\
\text { sutinku } \\
\text { Strongly } \\
\text { agree }\end{array}$ & $\begin{array}{l}\text { Sutinku } \\
\text { Agree }\end{array}$ & $\begin{array}{c}\text { Nežinau } \\
\text { Do not } \\
\text { know }\end{array}$ & $\begin{array}{l}\text { Nesutinku } \\
\text { Disagree }\end{array}$ & $\begin{array}{c}\text { Visiškai } \\
\text { nesutinku } \\
\text { Strongly } \\
\text { disagree }\end{array}$ \\
\hline 1. Panevėžys - pramonès miestas / Industrial city & 36 & 52 & 30 & 65 & 5 \\
\hline $\begin{array}{l}\text { 2. Panevèžys - patrauklus miestas turistams } \\
\text { Attractive tourists city }\end{array}$ & 5 & 23 & 51 & 90 & 19 \\
\hline $\begin{array}{l}\text { 3. Panevėžys - puikus miestas gyventi ir dirbti } \\
\text { Perfect city to work and live }\end{array}$ & 16 & 77 & 37 & 49 & 9 \\
\hline $\begin{array}{l}\text { 4. Panevèžys - Aukštaitijos kultūros centras } \\
\text { Cultural centre of Aukštaitija region }\end{array}$ & 43 & 83 & 22 & 32 & 8 \\
\hline $\begin{array}{l}\text { 5. Panevèžys - žalias, gamtiškas miestas } \\
\text { Green, natural city }\end{array}$ & 27 & 97 & 20 & 31 & 12 \\
\hline $\begin{array}{l}\text { 6. Panevėžys - puikus miestas pramogauti } \\
\text { Great place to entertain }\end{array}$ & 6 & 45 & 40 & 75 & 22 \\
\hline $\begin{array}{l}\text { 7. Panevèžys - sporto miestas } \\
\text { City for sport activities }\end{array}$ & 21 & 94 & 35 & 32 & 6 \\
\hline $\begin{array}{l}\text { 8. Panevėžys - verslo galimybių miestas } \\
\text { City for business }\end{array}$ & 6 & 41 & 61 & 58 & 21 \\
\hline $\begin{array}{l}\text { 9. Panevėžys - saugus ir ramus miestas } \\
\text { Safe and quiet city }\end{array}$ & 5 & 48 & 44 & 81 & 9 \\
\hline $\begin{array}{l}\text { 10. Panevėžys - miestas su mažai darbo vietų } \\
\text { City with lack of jobs }\end{array}$ & 45 & 94 & 26 & 21 & 2 \\
\hline $\begin{array}{l}\text { 11. Panevėžys - sovietinès išvaizdos miestas } \\
\text { City look reminds of soviet times }\end{array}$ & 24 & 45 & 35 & 71 & 12 \\
\hline $\begin{array}{l}\text { 12. Panevėžys - miestas, garsëjantis nusikalstamumu } \\
\text { Known as a crime city }\end{array}$ & 22 & 64 & 30 & 64 & 6 \\
\hline
\end{tabular}

Su teiginiu, kad miestas patrauklus turistams, 90 užpildžiusių apklausą asmenų pareiškè nesutinkantys su šiuo teiginiu. Respondentai mano, kad turistams nèra ką Panevėžyje pamatyti. Panevėžio miesto savivaldybès 2017-2019 m. veiklos plane (Panevezžio miesto savivaldybès..., 2017) pateikiama informaciją, kad užsienio turistai 2016 m. sudare $24 \%$ Turizmo informacijos centro lankytojų. Be to, atvykstančių ì miestą užsieniečių skaičius po truputi auga, tačiau miestas vis dar nèra pakankamai patrauklus, koks galètu būti. Su teiginiu, kad Panevèžys - puikus miestas pramogauti, nesutiko net 75 respondentai, 22 visiškai nesutiko. Pramogos yra viena iš priežas- čių, kodèl vykstama ị didesnius miestus, tikimasi platesnio spektro laisvalaikio praleidimo būdų, ìdomias paslaugas siūlančiu ìstaigų. Atrodo, kad apklaustieji nemato galimybių Panevéžyje maloniai leisti laisvalaikị.

Su teiginiu, kad Panevėžys - sovietinès išvaizdos miestas, kuriame yra daug kraštovaizdyje išsiskiriančių sovietinio stiliaus pastatų, nenorejo sutikti 71 apklausos dalyvis. Tai galima vertinti kaip patrauklaus miesto bruožą, kadangi žmonès nemano, kad miesto aplinka primena sovietinius laikus. Jiems miestas - gražus, modernus, šiuolaikiškas, miesto aplinka žmones tenkina. Nors Panevėžyje iki šiol yra išlikę nemažai sovietini 
laikmetị menančių objektų, pavyzdžiui, Santuokų rūmai, kino teatras „Garsas“, Sporto rūmai, respondentai to neakcentuoja ir bendros miesto išvaizdos nevadina sovietine.

\section{KULTŪROS IŠTEKLIỤ REIKŠMĖ PANEVĖŽIO MIESTO İVAIZDŽIUI}

Respondentai vertino, ar Panevèžyje yra pakankamai kultūros išteklių. Gauti rezultatai nevienareikšmiški: beveik po lygiai pasiskirstè respondentų vertinimas "ne“ ir „tikriausiai“, atitinkamai 36,7 ir $36,2 \%$. Taigi, dèl kultūros išteklių kiekio mieste gyventojų nuomonè nèra vieninga. Pusé respondentų abejoja, kad kultūros išteklių $\mathrm{Pa}$ nevėžyje pakanka arba nesijaučia pakankamai kompetentingi šioje srityje reikšti savo nuomonę. Vis dèlto toks abejojimas neužtikrina, kad kultūros išteklių kiekis pakankamas teigiamam miesto įvaizdžiui formuoti. Pasirinkusieji variantą "ne" turi didesnę ittaką formuojant neigiamą ịvaizdị apie Panevèži kaip miestą, kurio kultūrinèje sferoje gausu trūkumų. Tam, kad geriau pažintume miesto kultūrinę erdvę, susikurtume aiškesni vaizdą apie mieste esančių išteklių kieki ir pasiskirstymą, buvo sudarytas Panevėžio miesto kultūros išteklių žemėlapis (žr. 1 pav.). Jis atskleidžia ne tik visų miesto kultūros įstaigų, bet ir svarbiausių kultūros paveldo objektų buvimo vietą, parodo, kuriose miesto teritorijose aktyviai plètojama kultūrinè veikla.

Dalis apklausos dalyvių teigé, kad mieste kultūros išteklių yra nepakankamai, nurodè, kokių išteklių miestui trūksta. Vyravo nuomonè, kad labiausiai mieste trūksta kultūros renginių $(59,1 \%$ respondentų) ir kultūros objektų (paveldo objektų, monumentų ir kt.) (24,4 \% apklaustųjų). Toks vertinimas reiškia, kad miesto kultūrai yra skiriama mažai reklamos ir viešinimo arba patys gyventojai per mažai domisi mieste vykstančiais kultūriniais renginiais. Reikètų skatinti visuomenę įsitraukti ị kultūros veiklą, patraukliai viešinti tiek vykstančius renginius, tiek meninę veiklą, užsièmimus, atskleisti, kodèl naudinga ir i̇domu pažinti miesto kultūrą. Tikètina, kad tada gyventojai palankiau vertintu gyvenimo kokybę mieste, gerètų visuomenès užimtumas, galbūt mažiau asmenų emigruotų iš miesto.

Tyrimo metu buvo išsiaiškinta, kokiais konkrečiai kultūros ištekliais, respondentų nuomone, garsėja Panevėžys. Apklausos anketoje iš pateiktų 11 skirtingu kultūros ištekliu grupių respondentai galèjo rinktis vieną arba keletą atsakymo variantu, rezultatai pateikti 2 pav.

Atsakiusiųjų nuomone, labiausiai Panevėžio miestą garsiną teatrai ir jų veikla $(20,1 \%)$. Tai gana tikètinas rezultatas, kadangi, kaip jau buvo minèta, miestas išsiskiria teatrų ịvairove. Kai kurie žinomi ir pelnę pripažinimą jau seniai (Juozo Miltinio dramos teatras), kiti yra išskirtiniai tarptautiniu mastu (pavyzdžiui, Lèlių teatras).

Beveik lygiomis dalimis pasiskirstė dar keturių kultūros išteklių rūšių mieste vertinimai: 11,1 \% apklaustųjų pasirinko dailès kūrinius ir dailès parodas kaip miestą garsinančius kultūros išteklius; $11,2 \%$ teigia, kad miestą garsina bibliotekos ir ju kultūrinè veikla; $11,2 \%$ pasirinko šokio meną, šokių ansamblius bei kolektyvus; 11,4 \% mano, kad miestą geriausiai reprezentuoja fotografijos parodos. Galima teigti, kad miesto žmonès gana gerai susipažinę su kultūra, tačiau dažnai domisi tik tam tikromis meno rūšimis. Dažniausiai tai priklauso nuo respondentų amžiaus, pomėgių ar profesijos. Tačiau akivaizdu, kad Panevèžio kultūrinè erdvè turi daugybę nišų, kurioms galbūt nèra skiriamas vienodas dèmesys, nors jų potencialas garsinant miestą yra didžiulis. Jei visuomenè suvoktų, kokia įvairialypé yra miesto kultūrinė erdvè, tikrai geriau vertintų Panevèžĭ, padètų jam atskleisti unikalius kultūrinius bruožus ir tapti turizmo traukos centru.

Tyrimo metu respondentai išreiškè nuomonę, ar Panevèžio miesto ịvaizdis visuomenèje pagerètų, jeigu būtų skiriama daugiau dèmesio miesto kultūros ištekliams ir jų puoselèjimui. I ši klausimą respondentai atsake gana vieningai: iš 188 apklausoje dalyvavusių asmenų 114 (60,6 \% respondentų) pasirinko atsakymo variantą "taip“, 58 (30,9 \% respondentų) - „tikriausiai“, taigi, dauguma neabejoja, kad kultūros ištekliai yra vienas iš būdų Panevèžio miesto įvaizdžiui pagerinti. Variantą „ne“ pasirinko tik 11 respondentu (5,9 \% apklaustųjų), kurie, tikriausiai, nemano, kad Panevėžio miestą reprezentuoti turètų jo kultūrinè veikla.

Apklausos dalyviai ìvardijo, kas turi būti daroma kultūros srityje, kad miesto įvaizdis gerètų. $25 \%$ respondentų mano, kad miestui trūksta daugiau kultūros objektų ir renginių, kurie suteiktų jo įvaizdžiui patrauklumo, 24,7 \% - kad 







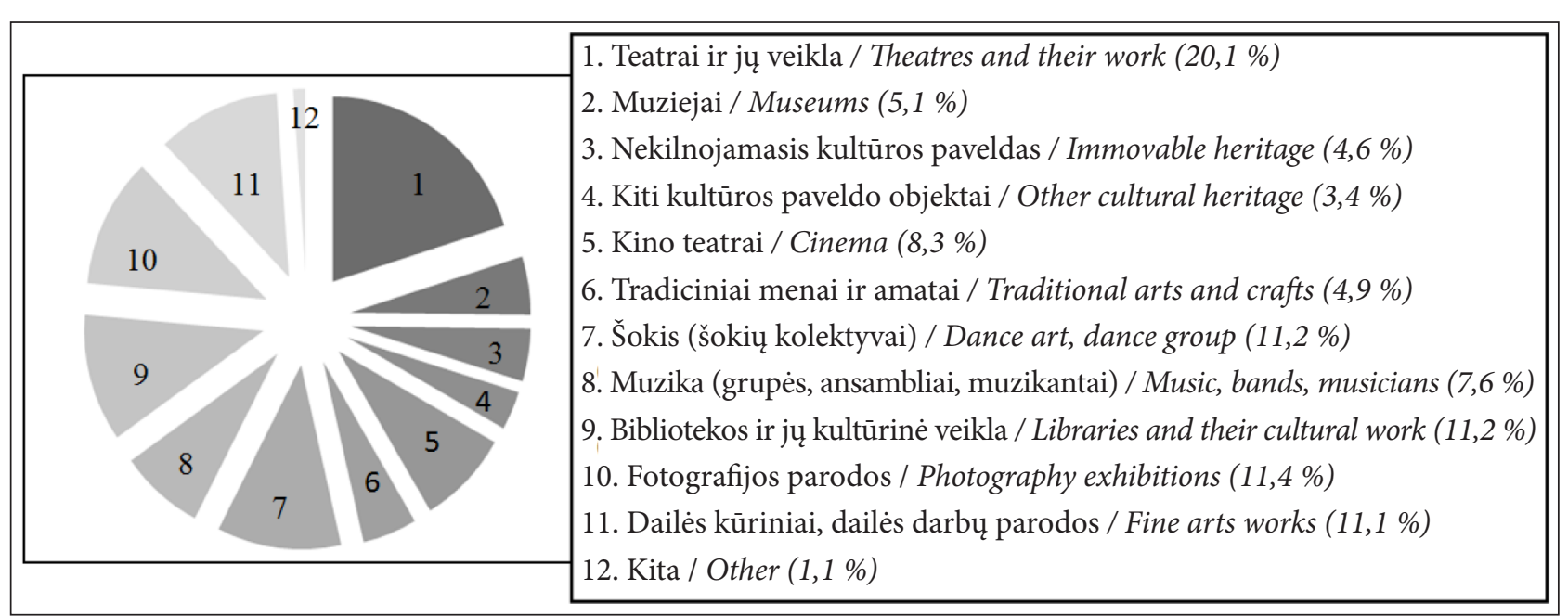

2 pav. Panevèzio miesto kultūros ištekliai

Fig. 2. Panevéžys city cultural resources

viskas priklauso nuo gyventojų iniciatyvos. Jeigu gyventojai i̇dètų daugiau pastangų bei prisidètų prie miesto kultūrinès sferos plètros, miesto ìvaizdis labai pagerètų. Trečias populiariausias atsakymas buvo kultūros objektų sutvarkymas. Jị rinkosi 18,6 \% užpildžiusiųjų anketą. Vadinasi, yra manančiųjų, kad Panevėžyje ne visi kultūros objektai, pastatai, paminklai yra geros būklès, tinkamai naudojami pagal paskirti, todèl jiems sutvarkyti miestas turètų rasti lèšų.

\section{IVAIZDŽIO FORMAVIMO PROBLEMOS IR PASIÚLYMAI}

Apklausos duomenys atskleidè, kad viena iš ịvaizdžio formavimo problemų yra silpna miesto ekonomika ir gyventojų užimtumas. Tai galejo prisidèti prie gyventojų mažejimo tendencijos - dar vienos iškeltos problemos. Tyrimo rezultatai ịrodé, kad gyventojai sutinka su tuo, jog kultūros ištekliai labai pagerintų miesto įvaizdì, o miesto ekonomikai duotų teigiamą postūmí.

Kita problema, neleidžianti miesto ịvaizdžiui tapti tokiam patraukliam koks galètų būti, yra mažai reklamuojami ir pristatomi Panevéžio kultūros ištekliai. Tai pasakytina ne apie visus kultūros išteklius, tačiau kai kuriems trūksta visuomenès dèmesio, informacijos apie juos, todèl nepakankamai atskleidžiamas Panevėžio miesto savitumas. Situacija nèra gera ir su kultūros ịstaigomis. Mieste labai vertinami teatrai, mégstamas kinas, miestas garsẻja dailès darbų parodomis, keramikos dirbiniais, dèl kultūrinès veiklos visuomenès dèmesio sulaukia bibliotekos. Tačiau, apklausos tyrimo duomenimis, respondentai mažiau vertina muziejų veiklą, kilnojamąji ir nekilnojamaji kultūros paveldą, Panevėžio miesto muzikinè veikla neitvardijama tarp populiariausių kultūros sričių. Patrauklesniam miesto ivaizdžiui formuoti gali padèti mažiau žinomu miesto kultūros išteklių reprezentavimas, nes tai suteiktų miestui naujų spalvų, atsirastų daugiau priežasčių turistams atvykti i̇ miestą, kiekvieno skoniui Panevėžys galètų pasiūlyti įdomaus laisvalaikio praleidimo galimybių. Be to, tai galètu sulaikyti gyventojus nuo emigracijos.

Dar vienas siūlymas, prie kurio buvo prieita rengiant ir analizuojant tyrimo medžiagą, yra rūpinimasis miesto aplinka. Tyrimas atskleidè, kad daugelis Panevėžio aplinkos elementų gyventojų netenkina. Pavyzdžiui, blogos būklès keliai, kurie kelia pavojų saugumui ir darko miesto estetinį vaizdą, apleisti, uždaryti ir vaiduokliais virtę pastatai, kurie tikrai nepuošia miesto ir jo teigiamai nereprezentuoja. Nors apklausos dalyviai nurodè, kad Panevèžys jiems neprimena sovietmečio, tačiau jame nemažai nesutvarkytu objektų (apleistų gamyklų, senų medinių namų), tiek ir kultūros paveldo, kuris galètų puošti miesto aplinką. Jei jie būtų pritaikyti visuomeninėms reikmėms, pagerètų ir kultūrinio turizmo situacija, kadangi jau būtų galima rodyti tokius objektus turistams kaip miesto istorinès raidos pavyzdžius. 


\section{IŠVADOS}

1. Atlikti miesto įvaizdžio vertinimą yra gana sudètingas procesas, kadangi jam susiformuoti itakos turi skirtingi veiksniai. Miestų ịvaizdis kiekvienam žmogui susiformuoja labai individualus, priklausomai nuo asmens suvokimo, todèl tai nebūtinai visapusiškai ir tiksliai atspindès realią miesto situaciją.

2. Panevėžio ịvaizdis Lietuvoje, apklausos duomenimis, daugiau vertintas vidutiniškai arba blogai. Neigiamų atsiliepimų sulaukè miesto keliai, ekonominè padètis, pramogų stygius. Palankiai ìvertintos žaliosios erdvès, sporto galimybès, miesto geografinè padètis. Tai suteikia miestui patrauklumo, tačiau nepakanka norint visapusiškai atskleisti miesto įvaizdžio potencialą. Reikètų atkreipti dèmesị $\mathfrak{x}$ silpnąsias miesto vietas ir stengtis jomis pasirūpinti.

3. Respondentai pritaria, kad kultūros ištekliai reikšmingi Panevėžio miesto įvaizdžiui. Tarp žinomiausių îvardyta daugelis meno rūšių: fotografija, šokis, daile, teatrai, biblioteku veikla ir t. t. Vadinasi, Panevėžio kultūrinė aplinka yra ịvairi ir įdomi, susijusi su miesto istorine raida ir praeitimi, galinti sèkmingai konkuruoti tarptautinèje erdvejje.

4. Jaučiamas informacijos apie miesto kultūrinę sferą trūkumas, menkas visuomenès suvokimas bei domejimasis ja, todèl respondentai abejoja, kad Panevėžyje yra pakankamai kultūros išteklių. Situaciją pagerintų didesnè visuomenès ir miesto valdžios iniciatyva kultūros srityje, nes jie turi didžiausią ịtaką formuojant miesto ìvaizdị.

Gauta 20171023

Priimta 20171208

\section{Literatūra}

1. Albrechtaitè-Lingienè G. 2012. A. Jasilionyte்: „Gerai parinktas ivaizdis isitvirtina“. http://top.scbmedia.eu/iq-zmogus/a-jasilionyte-apie-ivaizdzio-galias-ir-silpnybes/ (žiūrèta 20170307 ).

2. Anholt S. 2006. The Anholt-GMI city brands index: How the world sees the world's cities. Place Branding. 2(1): 19-31.

3. Dranseikaitè L. 2011. Kultūros įstaigos misija - atverti duris $i$ kitoki pasauli. https://www.naujienos. lt/leidinys/sekunde/kulturos-istaigos-misija-atverti-duris-i-kitoki-pasauli-nuotrauku-galerija/ (žiūrèta 201704 14).

4. Gilboa S., Jaffe Eugene D., Vianelli D., Pastore A., Herstein R. 2015. A summated rating scale for measuring city image. Cities. 44: 50-59.

5. Kultūros vertybiu registras. 2017. https://kvr.kpd. lt/\#/static-heritage-search (žiūrèta 201704 22).

6. Lietuvos sporto informacijos centras. $2015.2014 \mathrm{~m}$. miestu ir rajonu savivaldybiu sporto bazés. http:// www.sportinfo.lt/savivaldybiu-statistika/2014-msporto-bazes (žiūrèta 20170420 ).

7. Likert scaling. 2006. https://www.socialresearchmethods.net/kb/scallik.php (žiūrèta 201704 09).

8. Lynch K. 1960. The Image of the City. Cambridge: The Technology Press and Harvard University Press.

9. Maksimaitienè O. 2003. Panevéžio miesto istorija. Panevėžys: UAB Panevėžio spaustuvė.

10. Panevéžio miesto kultūros plètros studija. 2012. Vilnius: UAB Lyderio grupè.

11. Panevėžio miesto savivaldybès taryba. 2013. Panevéžio miesto pletros 2014-2020 metu strateginis planas. Rengejas Panevėžio miesto savivaldybès administracija.

12. Panevėžio miesto savivaldybès taryba. 2017. Panevěžio miesto savivaldybès 2017-2019 metu veiklos planas. Rengèjas Panevėžio miesto savivaldybès administracija.

13. Panevezzio miesto teritorijos bendrasis planas. Gamtinis karkasas ir bendro naudojimo bei rekreacijos teritoriju plètra. 2008. UAB Urbanistika.

14. Panevėžio miesto želdynu tvarkymo specialusis planas. Esama būklè. 2013. UAB „Vandens projektai“.

15. Robinson M. 2009. Kultūrinio turizmo patirtys. Iš: Kultūros paveldas ir turizmas. Galimybès, poveikis, partnerystè ir valdymas, sud. M. Lehtimäki. Vilnius. 
Ieva Ucinavičiūtè, Regina Prapiestienè

\section{PANEVĖŽYS CITY CULTURAL RESOURCES IN SHAPING THE CITY IMAGE}

\section{Sum mary}

The aim of this work is to find out whether the cultural resources of Panevėžys city have any impact on forming its image. Nowadays it is essential for a city to have a proper image in order to attract more investments, tourists, potential residents, as these factors give the city an opportunity to develop. An analysis of particular literature shows that city image depends on various aspects. That includes physical elements of city environment, like paths, districts, nodes, landmarks, public reports of social media, celebrities or even other people's personal opinion, but the most important is how people perceive these aspects. Our perception of the surrounding shapes our own individual city image.

Suitably presented cultural resources can be a way of promoting city and inducing people to visit it. In the past, Panevežys was prominent as a cultural center of the region regarding the theatre, music, other art associations, institutions of education. After the re-establishment of independence of Lithuania, Panevėžys cultural situation remained nearly unchanged. Now many international cultural events occur there, like ceramic symposiums, photography biennales. Art institutions, galleries, theatres and cinemas keep working on making a more sophisticated society.
The research of this work was accomplished by doing a survey which helped to elucidate that city dwellers have a positive opinion on the image of the city. Panevėžys is considered a cultural centre of Aukštaitija region and the people are pleased about green spaces in the city, decent sport infrastructure and city geographical position in Lithuania. What is negative about the city is a weak economic situation, poor quality of city streets and roads, lack of activities including workplaces and leisure. These factors detract the image of Panevèžys.

The society accepts the idea that cultural resources have a significant meaning in building the image of Panevėžys. A vast majority of cultural events and celebrated members of art industry proclaim the name of Panevéžys in Lithuania and abroad. People admit that Panevėžys city has a unique and rich cultural resources potential and effective usage can lead to a better image. The city lacks publicity of cultural resources such as music, dance, photography, cultural heritage objects. The society is poorly educated and a vast majority of people do not show any personal interest in city cultural resources. Nevertheless, city residents and the government are considered to be responsible for a certain city image, so the collaboration of these two powers and initiative actions for the common goal can lead the city to success.

Keywords: culture, cultural resources, city image, image formation, factors of image formation 